\title{
Derecho del Consumo
}

\section{Francisca Barrientos Camus}

Profesora de Derecho Civil

Universidad Diego Portales

Investigadora Fundación Fernando Fueyo

LA RESPONSABILIDAD DEL QUE ARRIENDA MÓDULOS DE TRABAJO CAUSADA POR LAS QUEMADURAS FACIALES OCASIONADAS A LA CONSUMIDORA

Se describe en el fallo que comento, Muñoz con Peluquerías Integrales, Corte de Apelaciones de Chillán, 7 de abril de 2014, rol No99-2013, CL/ JUR/1001/2014, que una consumidora acudió a una peluquería para realizarse un tratamiento facial con el objetivo de acudir al matrimonio de su hermana. La persona que la atendió no cuidó de verificar el estado de los productos provocándole severas quemaduras en su rostro. Por esta razón, la consumidora interpuso una querella infraccional y una demanda civil, las que fueron acogidas.

Para efectos del comentario interesa analizar

1) la legitimación pasiva de la empresa querellada y demandada y

2) la infracción de la seguridad en relación con la prueba del daño.

\section{1.- LA CALIDAD DE PROVEEDOR} DEL QUE ARRIENDA MÓDULOS DE TRABAJO

De este modo, conviene examinar un ámbito poco estudiado en sede de con- sumo, que tiene relación con la legitimación pasiva de los querellados y demandados que invocan la falta de un vínculo directo con el consumidor para abstenerse de responder por los perjuicios sufridos por las víctimas.

Este problema se presenta con frecuencia en las causas de estacionamientos, y ahora a propósito de otro tema relacionado con la seguridad en el consumo se tiene la ocasión de comentar.

Tal y como sucedió en este caso, la empresa proveedora se intentó eximir de su responsabilidad infraccional y civil alegando que la causante del daño no era ella, sino la persona que le arrendaba un módulo de trabajo.

Si se lee el artículo $1 \mathrm{~N}^{\mathrm{O}} 2$ de la ley sobre protección de los derechos de los consumidores se ve que contiene una voz amplia, que considera a los proveedores como:

"las personas naturales o jurídicas, de carácter público o privado, que habitualmente desarrollen actividades de producción, fabricación, importación, construcción, distribución o comercialización de bienes o de prestación de servicios a consumidores, por las que se cobre precio o tarifa", 
lo que sugiere que cualquier clase de prestación de servicios por los que se cobre un precio o tarifa supone quedar dentro del ámbito de aplicación de esta legislación.

Si se analiza el funcionamiento de las peluquerías -y de otras empresas proveedoras en general-, es posible observar que cada persona que presta un servicio entrega una boleta de prestación de servicios. De modo que cuando los clientes o clientas pagan, reciben esas boletas, sin que conste en ninguna parte el nombre de la empresa que las agrupa. Y esta situación fáctica (y laboral), ¿̇significa que la empresa no tiene injerencia alguna respecto de la labor de cada persona que "arrienda el módulo de trabajo"?

Si se considera como proveedora solo a la persona que presta de forma material el servicio, sin tomar en consideración que la empresa que dispone el espacio físico, el nombre, la marca, la publicidad, entre otras, pienso que se desconocería la realidad de la empresa proveedora, la que por una serie de motivos -que en estas líneas no cabe considerar-ha ordenado arrendar sus puestos de trabajos.

Si no se tomara en cuenta esta realidad, supondría desconocer la plena vigencia del recurso de la buena fe, en el sentido que obliga a más allá de lo literal de las palabras -ex artículo 1546 del Código Civil-. Argumento que debería sopesarse para otorgarle plena protección al consumidor ampliando la órbita contractual, que desconoce la relación interna entre estas personas. Y por ello, aquí vemos un punto de conexión con la rama del Derecho Laboral que reconoce la primacía de la realidad sobre lo dispuesto en las apariencias de las formas jurídicas.

En suma, en el ámbito del consumidor fuerza reconocer la realidad de las cosas. Por ese motivo, la empresa denunciada y demandada no puede excusarse de la relación interna, bajo la justificación que solo arrienda puestos de trabajo para no ser considerado como proveedor conforme lo dispone el artículo $1 \mathrm{~N}^{\mathrm{o}} 2$ de la ley sobre protección de los derechos de los consumidores.

Dicho esto, ahora conviene examinar la seguridad de la persona en el ámbito del consumo.

\section{2.- El CUIDAdo DE LA PERSONA, LA SEGURIDAD EN EL CONSUMO Y LA PRUEBA DEL DAÑO}

La seguridad en el consumo se consagra como un derecho irrenunciable para el consumidor, se que se traduce en un deber para el proveedor (artículo 3 letra d y 4).

Si bien, la regla establece el amparo de la seguridad "en el consumo de bienes o servicios", lo que podría dar a entender que solo las cosas o el patrimonio estaría tutelado; en realidad la ley (y no solo esta ley) cuida de la persona misma en este ámbito especial.

Es cierto, en sede de consumo por disposición especial de la ley, el proveedor debe cuidar a la persona consumidora, tal como ocurre en el ámbito del trabajo comprometiéndose a no dañarla durante todo el íter contractual.

De este modo, se ha configurado una obligación ex lege de seguridad del 
proveedor que influye en el contrato e incluso fuera del él, como en las materias extracontractuales.

Sin embargo, no es posible dejar de observar la influencia de la responsabilidad infraccional para la configuración del ilícito civil.

Así, adquiere especial relevancia la infracción al artículo 23 de la ley, norma infraccional que se relaciona de forma directa con la responsabilidad civil al tipificar como un ilícito infraccional el incumplimiento negligente de las obligaciones del contrato.

En este caso, la Corte consideró que había negligencia en la prestación del servicio, circunstancia que además motiva la responsabilidad infraccional. Apreciando los hechos conforme a las reglas de la sana crítica, se consideró que la consumidora que sufrió quemaduras en la cara por cera caliente, presentando además, manchas hiperpigmenticias producto de la inflamación por la quemadura (considerando $4^{\circ}$ ):

"por lo que el actuar del mencionado establecimiento comercial lo fue con negligencia, al no prestarle un servicio a la consumidora con la seguridad suficiente, lo cual permite presumir la existencia de un daño y de una aflicción por parte de la querellante, que se concretaron en las lesiones que le fueron causadas" (las cursivas son mías, considerando $6^{\circ}$ ).

Así, si se siguen los considerandos transcritos, será posible apreciar que el juez y la Corte consideraron la existencia de la negligencia infraccional, y consecuencialmente civil, por la falta de seguridad en la prestación del servicio; y con ese antecedente, "presumieron" la existencia del daño.

En realidad, si la responsabilidad infraccional está ligada de manera íntima a la civil, y si es cierto que aquella constituye una derivación de la responsabilidad penal, debería probarse la culpa; y con ello, se configuraría una clase de culpa contra la legalidad o culpa infraccional en sede civil que permitiría dar por probada esta exigencia.

En estos términos, la consumidora debería demostrar el daño y el nexo de causalidad. Sobre este último requisito la sentencia no se pronuncia en ninguno de sus considerandos.

Y como es posible observar, respecto de la prueba del daño, al parecer se configuró una presunción, eso es lo que infiere de los términos de la sentencia, con lo que se estaría haciendo aplicable algo similar al res ipsa loquitur, aunque sin la argumentación necesaria.

En este orden de ideas, el considerando $7^{\circ}$ de la sentencia establece:

"Que, bajoelcontextofácticodescrito en el fundamento anterior, en el sentido de que hubo una conducta negligente de la empresa querellada al aplicarle por una de las personas que allí laboraba un producto en el rostro de la querellante, poniendo en riesgo la seguridad de dicha consumidora, al provocarle lesiones a consecuencia de su aplicación, dicho hecho constituye una infracción de los artículos $3^{\circ}$ letra d) y 23 de 
la Ley $\mathrm{N}^{\circ} 19.496$, toda vez que la querellada no adoptó oportunamente las medidas preventivas de seguridad que dicha situación ameritaba, causándole un menoscabo a la consumidora por lo que merece ser sancionada contravencionalmente".

Idea que se reitera a propósito del análisis de la acción civil de indemnización de perjuicios, en términos que:

“...esta Corte estima que la sola infracción de las disposiciones de la Ley 19.496 en perjuicio de un consumidor, unido al hecho cierto que debió ocurrir al órgano jurisdiccional para reclamar 418 de aquella, permiten presumir la existencia de un daño y de una

aflicción, que en la especie se concretó en las molestias sufridas por la demandante a raíz de las quemaduras sufridas en su rostro" (considerando $13^{\circ}$ ).

Por estas consideraciones, la Corte de Chillán, al parecer presumió la culpa civil y el daño, solo con la contestación de la responsabilidad infraccional, y con esos antecedentes condenó a la empresa con una multa a beneficio municipal de 10 UTM y $\$ 1.500 .000$ a título de indemnización, confirmando la sentencia apelada sin costas.

Si bien, dicha solución parece acertada, para efectos de este comentario habría que recordar la importancia distinguir cada uno de los elementos que configuran la responsabilidad infraccional y civil, y su prueba. 